DOI 10.18551/rjoas.2019-09.30

\title{
BALANCED SCORECARD IMPLEMENTATION IN THE GOVERNMENT HOSPITAL
}

\author{
Widyasari Ni Luh Gde ${ }^{\star}$, Adi Nyoman Rasmen \\ Undiknas Graduate School, Denpasar, Bali, Indonesia \\ `E-mail: widyamaniknalini@gmail.com
}

\begin{abstract}
This research is about the implementation of Balanced Scorecard in the government hospital and performance achievement using the Balanced Scorecard, that proxied by four perspectives such as financial perspective, customer perspective, internal business process perspective, learning, and growth process. A quantitative descriptive approach was used in this study. The technique of collecting data used in this study was participant observation, structured interviews, semi-structured interviews, and documentation. Bali Mandara Hospital of Bali in 2018 based on the Strategic Business Plan is going well. The total of the final score of Balanced Scorecard final score of four perspectives is $65.75 \%$. It shows a very good condition with category A. Target of the financial perspective in 2018 is $100 \%$. Financial perspective exceeded the target with an ratio of effectiveness of $161.39 \%$. Target for customer perspective is $90 \%$ however, the target is not achieved. Internal business processes also not achieve from $80 \%$ target. Target for learning and growth perspective is $60 \%$. Only employee satisfaction achieved to $74.72 \%$.
\end{abstract}

\section{KEY WORDS}

Balanced scorecard, Bali, strategy, management, hospital.

The quality and professional hospital performance is increasingly being demanded because the success of hospital performance is also determined by the community. The hospital performance must be managing a clear and precise management concept, so that it can make quality and growth of hospital abroad. UPTD Bali Mandara Hospital is a hospitalowned by the Government of the Province of Bali as a Pattern of Financial Management in the Regional Public Service Board (PPK-BLUD). Hospitals are required to draw up a Strategic Business Plan to become a Regional Public Service Agency (BLUD). Achievement of a hospital's performance can be measured by the Balanced Scorecard approach which measures performance based on four perspectives including financial perspective, customer perspective, internal business process perspective, learning, and growth perspective. The four perspectives on the Balanced Scorecard are interconnected and have a causal relationship.

UPTD Bali Mandara Hospital has prepared and implemented a Strategic Business Plan based on the perspective of the Balanced Scorecard in the next five years from 2018 to 2022. Therefore, to find out the hospital's performance both financially, non-financially and cause-and-effect relationships between the four perspectives, It is deemed necessary to conduct a study on the application of the Balanced Scorecard application in UPTD Bali Mandara Hospital.

The purpose of this study was to determine the implementation of the Balanced Scorecard as a performance measurement tool at UPTD Bali Mandara Hospital and to determine the achievement of hospital performance using the Balanced Scorecard. The period used in this study is relatively short, namely only in 2018, because a new hospital was opened to the community on October 28,2017 , so possible data is taken for research only in 2018.

\section{LITERATURE REVIEW}

In the past, many companies used traditional performance measurement systems that measured the success of a company's financial performance only. The era of globalization of 
traditional measurement systems is not effectively used. Seeing these shortcomings, Robert S. Kaplan a Professor from Harvard Business School and David P. Norton from the U.S.A. in 1990 the Nolan Norton Institute research section of the KPMG public accountant office in U.S.A led by David P. Norton conductrd a study about "Performance Measurement in Future Organizations". The object of the study was conducted using 12 companies including American Standard, Bell South, Advanced Micro Devices, Apple Computer, Corner Peripherals, Dupont, Cray Research, CIGNA, General Electric, Hewlett-Packard, Shell Canada, and Electronic Data Systems. In 1996 Robert S. Kaplan announced a performance measurement system suitable for companies in the globalization era. It called the Balanced Scorecard. Mid-1993 Renaissance Solutions, In. (RSI) a consulting company led by David P. Norton applies the Balanced Scorecard as an approach to translating and implementing strategies in various client companies. The Balanced Scorecard not only for measured an executive performance but also developed into the core of a strategic management system (Mulyadi, 2018).

Balanced Scorecard consists of two words namely Balanced which means balanced and Scorecard which means scorecard. The meaning of balanced is the performance measured in a balanced way with two sides, namely the financial side and the non-financial side, which includes the short term and long term by involving internal and external parts. Understanding the scorecard is a card that is used to record the scores of current performance results and for future planning (Rangkuti, 2018). The Balanced Scorecard presents a set of strategic goals that are defined by the company, each of which is then assigned to one of the four perspectives and ultimately leads to financial success with a causal chain (Hansen \& Scaltegger, 2016).

Koesomowidjojo (2017) states that by utilizing the Balanced Scorecard on measuring the performance of an organization, it gets a picture of long-term action. Applying the Balanced Scorecard is useful for significant strategic planning realization, including the process of long-term planning. The use of the Balanced Scorecard also affects individual paradigms in the organization so that there is involvement in each segment and strategic plan (Martello, Watson, \& Fischer, 2016).

Performance measurement in the Balanced Scorecard consists of four perspectives including financial perspective, customer perspective, internal business process perspective, growth perspective, and learning are described as follows:

1. Financial perspective performance can be measured using three indicators (Anggraini and Nuraina, 2014). The three indicators on the performance of a financial perspective include:

- The economic ratio is the relationship between the value of money and the input of purchasing goods and services at the desired quality at the lowest price;

- The efficiency ratio is the ratio used to obtain revenue with the realization of income received;

- The effectiveness ratio is generally related to measures of ability to achieve certain targets that indicate the ability of governments to mobilize revenue revenues.

2. Customer perspective performance can be measured using three indicators, including:

- The level of customer satisfaction is to find out how much customer satisfaction. It is done by using a questionnaire as a data collection tool (Koesomowidjojo, 2017);

- Customer retention is the level at which a company can maintain relationships with regular customers (Anggraini and Nuraina, 2014);

- Customer acquisition is the number of new customers the hospital has acquired (Anggraini and Nuraina, 2014).

3. The performance perspective of internal business processes can be measured using two indicators, including:

- The process of innovation is understanding customer needs to be key in creating new products or services, so it is necessary to know the level of innovations (Koesomowidjojo, 2017); 
- The operational process is to state that performance measurement and monitor the efficiency of hospital bed occupancy use four parameters (Sudra, 2010). The parameter in the operational process is the BOR (Bed Occupancy Ratio) is the percentage of bed use in hospitalization, LOS (Length of Stay) is the number of calendar days for patients receiving inpatient care in hospitals and recorded as inpatients until out alive. or die from the hospital, TOI (Internal Turn Over) is the average number of bed days that are not occupied for patient care, BTO (Bed Turn Over) is the average number of patients who use a bed in a certain period.

4. Learning and Growth Perspective Performance. Koesomowidjojo (2017) states that the performance of learning and growth perspectives can be measured using three indicators including:

- The percentage of employee training is a measurement carried out to find out the percentage of employees who have expertise and are skilled in their fields in the organization;

- Employee productivity is a measurement that focuses on human resources that analyzes how business impacts improve morale and work environment conditions;

- Employee satisfaction is a measurement carried out to find out how much the satisfaction of employees who work in its influence on the growth and development of the organization.

The strategy map is used as a tool to visualize objectives. This visualization illustrates priorities and reveals the relationship between goals. In every hospital there is no similarity in the organization, this is because every hospital realizes not only aims at the economy but also on sustainable development (Niemiec, 2016). Strategic goals are future goals that the organization wants to achieve as a translation of strategies to realize the vision and goals (Mulyadi, 2018).

\section{METHODS OF RESEARCH}

This research used a quantitative descriptive approach. This approach aims to explain the phenomena that exist by using numbers, assessing the nature of the conditions that appear. The data analysis was done after all data has been collected and directed to search for percentages, means or modes (Syamsuddin \& Damaianti, 2011).

The type of data in this study consisted of quantitative data and qualitative data. The data source of this study consisted of primary data and secondary data. Data collection techniques used in this study were participant observation, structured interviews, semistructured interviews, and documentation. The sampling technique at the learning and growth perspective used was nonprobability sampling. Performance measurement from the perspective of learning and growth researchers collected 30 employee sampling data that were randomly assigned to units that were met by chance. Sampling techniques based on accidental or accidental sampling were people who are considered appropriate and accidentally meet who can be sampled by researchers (Sugiyono, 2016).

Data analysis conducted in this study was data collection (data collection), data condensation (data condensation), data presentation (data display), verification/conclusion drawing. This study uses a triangulation method and performance measurement analysis in testing the credibility of the data obtained.

\section{DISCUSSION OF RESULTS}

Estimating the hospital performance target used a standard increase of $10 \%$ every year. Estimates are expected to be precise but the possibility also misses, this can be influenced by strategic environmental factors. Factors that can affect include an internal capacity of hospitals in providing quality health services, public health conditions, competition in the world of medicine and plenary and affordable. Estimated target of hospital performance in 2018 at a financial perspective of $100 \%$, a customer perspective of $90 \%$, an internal business process perspective of $80 \%$, a growth and learning perspective of $60 \%$. 
Economic ratios per quarter for 2018 shows an increase in APBD spending in the first quarter by $1.77 \%$, quarterly II by $5.52 \%$, quarterly III by $12.04 \%$, and quarterly IV by $39.94 \%$. The total realization of APBD expenditure in 2018 was $R p .134,323,903,544.21$ and the budget was Rp.214,826,407,900.00 with a percentage calculation of $62.53 \%$.

The efficiency ratio shows the realization of the first quarter BLUD spending of $1.87 \%$, the second quarter II of $21.31 \%$, the third quarter III of $47.61 \%$ and the quarterly IV of 92.82\%. The total realization of BLUD expenditure in 2018 was Rp. 17,035,123,451.00 and the realization of revenue was $\mathrm{Rp} .32,730,642,237.54$ with the calculation of the percentage of $52.05 \%$.

The effectiveness ratio in quarterly I was $20.62 \%$, quarterly II was $38.14 \%$, third quarter III was $43.75 \%$ and quarterly IV was $58.88 \%$. The total effectiveness ratio in 2018 was Rp.32,730,642,237.54 and the revenue target set was Rp.20,281,000,000.00 with the calculation of the percentage of $161.39 \%$. Performance on a financial perspective is only the ratio of effectiveness that has exceeded the target.

Level of customer satisfaction UPTD Bali Mandara Hospital in the first quarter amounted to $81.40 \%$, quarterly II amounted to $82.78 \%$, quarterly II amounted to $85.49 \%$, quarterly IV $87.65 \%$. The total average value of respondents in 2018 was 202,895 with the highest number of scores of 240,232 . The total percentage of satisfaction levels was $84.46 \%$.

Customer retention shows that quarterly I was $19.52 \%$, quarterly II was $17.07 \%$, third quarter III was $21.31 \%$, quarterly IV was $71.66 \%$. The results of the percentage of customer retention in 2018 amounted to $47.60 \%$. Total old customers in 2018 were 10,399 people with a total of 21,848 customers. The results of the percentage of customer retention in 2018 amounted to $47.60 \%$.

Hospital customer acquisition in the quarter I was $80.48 \%$, quarter II was $82.93 \%$, quarter III was $78.69 \%$, quarter IV was $28.34 \%$. The total number of patients who came in 2018 was 21,848 people, while the number of new patients who came was only 11,449 people. The percentage of hospital customer acquisition in 2018 is $52.40 \%$. Performance on the customer's perspective does not reach the target.

The innovation process in 2018 cannot be carried out due to the limited budget available. In the internal process calculation the BOR score gets a score of -1 , LOS gets a score of 1 , TOI gets a score of -1 , BTO gets a score of -1 . The overall total score scores 1 . Performance from the perspective of internal business processes no one reaches the target.

Employees at UPTD Bali Mandara Hospital that has participated in training in 2018 totaling 331 people. The percentage of skilled employees in 2018 is $40.12 \%$. Employee productivity in 2018 was obtained from revenue divided by the number of employees amounting to Rp.19,024,871.26 then this result was further divided by net income of Rp.15,695,518,786.54. Calculation of the percentage of employee productivity of $0.12 \%$.

Employee satisfaction in 2018 obtained a total average value of respondents totaling 2,518 with the highest total score of 3,370. The results of the calculation of the percentage of $74.72 \%$. Performance on the perspective of learning and growth is only employee satisfaction that has exceeded the target value set.

Determining the weights for each indicator can be done by first determining the basic plan before taking action (brainstorming). Action is taken by determining the level of importance that becomes the priority target in the short term (Rangkuti, 2018). The weighting of indicators and maximum weighted scores is presented in Table 1.

Based on the results of the calculation of the total final value obtained then determined the standard criteria of performance appraisal presented in Table 2.

The total final value obtained is $65.75 \%$, it means UPTD Bali Mandara Hospital in Bali Province in 2018 is included in a very healthy condition with category $A$.

Strategic objectives within the framework of the Balanced Scorecard are arranged in a mapping strategy so that it is easy to see the interrelationships between the four perspectives namely financial perspective, customer perspective, internal business process perspective, growth and learning perspective (Rangkuti, 2018). Mapping strategy diagrams can illustrate and reveal the causal relationship between the objectives in the hospital and can lead to a better understanding of the Balanced Scorecard. Strategic targets that exist in 
the four perspectives in the Balanced Scorecard to be clearer then these goals are translated into strategic sub-goals. The strategy map diagram is presented in Figure 1.

Table 1 - Weight of Indicators and Maximum Weighted Scores

\begin{tabular}{|c|c|c|c|c|c|c|c|c|c|c|c|}
\hline No & Perspective & $\begin{array}{c}\text { Key } \\
\text { Performance } \\
\text { Indicators } \\
\text { (KPI) }\end{array}$ & $\begin{array}{c}\text { Number } \\
\text { of } \\
\text { Indicators }\end{array}$ & $\begin{array}{l}\text { Maximum } \\
\text { Indicator } \\
\text { Score }\end{array}$ & Weight & $\begin{array}{c}\text { Indicator } \\
\text { Weight }\end{array}$ & $\begin{array}{l}\text { Maximum } \\
\text { Weighted } \\
\text { Score }\end{array}$ & $\begin{array}{l}\text { KPI } \\
\text { Value }\end{array}$ & Value & $\begin{array}{l}\text { Indicator } \\
\text { score }\end{array}$ & $\begin{array}{l}\text { Weighted } \\
\text { score }\end{array}$ \\
\hline \multirow{3}{*}{1} & \multirow{3}{*}{ Finance } & $\begin{array}{c}\text { Economic } \\
\text { Ratio }\end{array}$ & \multirow{3}{*}{3} & \multirow{3}{*}{4} & \multirow{3}{*}{30} & \multirow{3}{*}{10} & \multirow{3}{*}{120} & $62,53 \%$ & B & 3 & \multirow{3}{*}{100} \\
\hline & & $\begin{array}{c}\text { Efficiency } \\
\text { Ratio }\end{array}$ & & & & & & $52,05 \%$ & $\mathrm{~B}$ & 3 & \\
\hline & & $\begin{array}{c}\text { Effectiveness } \\
\text { Ratio }\end{array}$ & & & & & & $161,39 \%$ & A & 4 & \\
\hline \multicolumn{10}{|c|}{ Total Weighted Score } & 10 & \\
\hline \multirow{3}{*}{2} & \multirow{3}{*}{ Customers } & $\begin{array}{c}\text { Satisfaction } \\
\text { Level }\end{array}$ & \multirow{3}{*}{3} & \multirow{3}{*}{4} & \multirow{3}{*}{27} & \multirow{3}{*}{9} & \multirow{3}{*}{108} & $84,46 \%$ & A & 4 & \multirow{3}{*}{90} \\
\hline & & $\begin{array}{l}\text { Customer } \\
\text { Retention }\end{array}$ & & & & & & $47,60 \%$ & B & 3 & \\
\hline & & $\begin{array}{c}\text { Customer } \\
\text { Acquisition }\end{array}$ & & & & & & $52,40 \%$ & $\mathrm{~B}$ & 3 & \\
\hline \multicolumn{10}{|c|}{ Total Weighted Score } & 10 & \\
\hline \multirow{2}{*}{3} & \multirow{2}{*}{$\begin{array}{c}\text { Internal } \\
\text { Business } \\
\text { Process }\end{array}$} & $\begin{array}{c}\text { Innovation } \\
\text { Process }\end{array}$ & \multirow{2}{*}{2} & \multirow{2}{*}{4} & \multirow{2}{*}{25} & \multirow{2}{*}{12,5} & \multirow{2}{*}{100} & 0 & $\mathrm{D}$ & 1 & \multirow{2}{*}{25} \\
\hline & & $\begin{array}{c}\text { Operational } \\
\text { Process }\end{array}$ & & & & & & - & $\mathrm{D}$ & 1 & \\
\hline \multicolumn{10}{|c|}{ Total Weighted Score } & 2 & \\
\hline \multirow{3}{*}{4} & \multirow{3}{*}{$\begin{array}{l}\text { Learning } \\
\text { and Growth }\end{array}$} & $\begin{array}{c}\text { Percentage } \\
\text { of Skilled } \\
\text { Employees }\end{array}$ & \multirow{3}{*}{3} & \multirow{3}{*}{4} & \multirow{3}{*}{18} & \multirow{3}{*}{6} & \multirow{3}{*}{72} & $40,12 \%$ & B & 3 & \multirow{3}{*}{48} \\
\hline & & $\begin{array}{c}\text { Employee } \\
\text { Productivity }\end{array}$ & & & & & & $0,12 \%$ & $\mathrm{D}$ & 1 & \\
\hline & & $\begin{array}{c}\text { Employee } \\
\text { Satisfaction }\end{array}$ & & & & & & $74,72 \%$ & A & 4 & \\
\hline & & & & tal Weighte & Score & & & & & 8 & \\
\hline & & & TOTAL & & & & 400 & & & & 263 \\
\hline
\end{tabular}

Table 2 - Criteria for Performance Appraisal Standards

\begin{tabular}{|c|c|c|}
\hline CONDITION & CATEGORY & TOTAL SCORE \\
\hline \multirow{3}{*}{ VERY HEALTHY } & AAA & $\geq 95$ \\
\hline & $\mathrm{AA}$ & $80<\mathrm{TS}<95$ \\
\hline & A & $65<$ TS $<80$ \\
\hline \multirow{3}{*}{ UNWELL } & BBB & $50<\mathrm{TS}<65$ \\
\hline & BB & $40<\mathrm{TS}<50$ \\
\hline & $\mathrm{B}$ & $30<\mathrm{TS}<40$ \\
\hline \multirow{3}{*}{ NOT HEALTHY } & $\mathrm{CCC}$ & $20<\mathrm{TS}<30$ \\
\hline & $\mathrm{CC}$ & $10<\mathrm{TS}<20$ \\
\hline & $\mathrm{C}$ & $\mathrm{TS}<10$ \\
\hline
\end{tabular}

Source: Rangkuti (2018).

Based on Figure 1, Strategic objectives can be related to performance measurements found in all four perspectives in the Balanced Scorecard. Analyzing mapping strategy diagrams starts from the perspective of learning and growth. The achievement of learning and growth perspective performance at the level of employee productivity and skilled employees has not reached the target. Strategic objectives of learning and growth perspective can be achieved if the hospital does not recruit too many employees and is more selective in selecting employee competencies because the new hospital is established. Too many employees are available in 2018 resulting in only a few employees getting training. The provision of training for each employee can affect the motivation and responsibilities of employees at work.

In the operational process, only LOS (Length of Stay) reaches an ideal standard value, so the quality of service in hospitals needs to be improved. Strategic objectives from the perspective of internal business processes can be achieved if the hospital improves the quality of service by increasing the quality of employees. The innovation process can be achieved if the quality of the instrument is further improved and heeded. Process quality, target quality, and instrument quality greatly influence the perspective of customers in the hospital. 
There is no achievement of the performance on the customer's perspective, the strategic goals on customer satisfaction and user satisfaction have not been achieved. Strategic targets on the customer's perspective will be achieved if the hospital improves the performance of its employees and always innovates products and more often promotes products to the community.

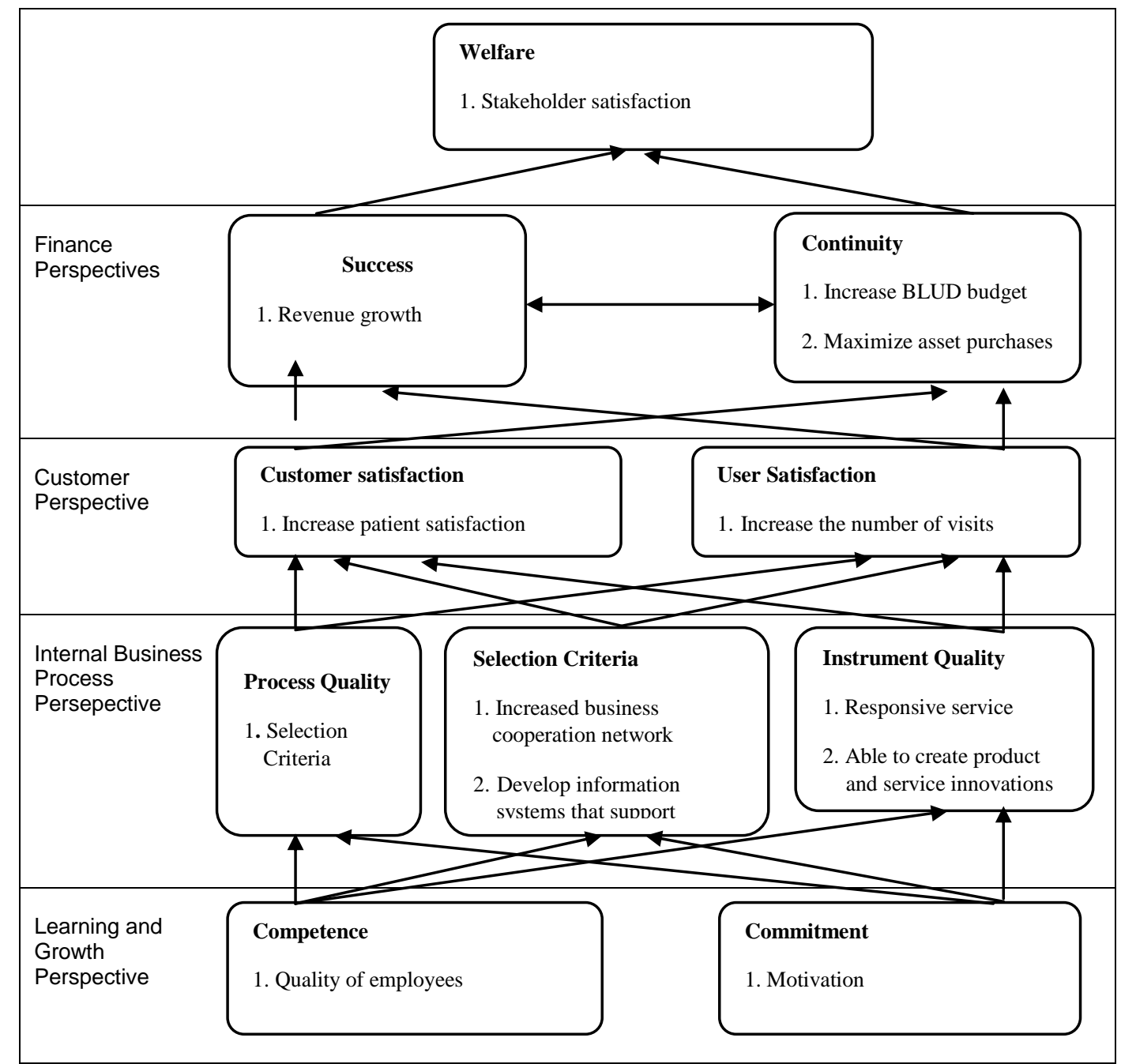

Figure 1 - Diagram of UPTD Bali Mandara Hospital Mapping Strategy

The results of achieving financial perspective performance on effectiveness ratios have exceeded the target. This achievement affects the strategic objectives of the financial perspective. The increase in hospital revenue growth affects the increase in the budget of the Regional Public Service Agency (BLUD) to maximize the purchase of hospital assets. Revenue growth also affects stakeholder welfare and increases employee services. The provision of high services greatly affects the commitment of employees at work.

Balanced Scorecard performance measurement results at UPTD Bali Mandara Hospital, when related to the strategic goals prepared by the hospital, showed that only a strategy to improve financial performance was achieved while the strategy to improve the quality of services has not been achieved.

\section{CONCLUSION AND SUGGESTIONS}

Based on the discussion above, the conclusions in this study are the implementation of the Balanced Scorecard at UPTD Bali Mandara Provincial Hospital in Bali in 2018 based on the Strategic Business Plan has been implemented well. The results of the total final value 
from the measurement of the four perspectives contained in the Balanced Scorecard that is equal to $65.75 \%$ included in a very healthy condition with category $A$.

The hospital target in the 2018 financial perspective is $100 \%$. Achievement of performance in the financial perspective that exceeds the target only at the effectiveness ratio that is equal to $161.39 \%$. The target set by the hospital at the customer's perspective is $90 \%$. Achieving performance on the customer's perspective does not reach the target. The target set by hospitals in the perspective of internal business processes is $80 \%$. Achievement of performance from the perspective of internal business processes did not reach the target. The target set by the hospital on the perspective of learning and growth of $60 \%$. Achieving performance that has exceeded the target is only at the level of employee satisfaction that is equal to $74.72 \%$.

This research is expected to be an additional reference in the concept of implementing the Balanced Scorecard. The results of this study are expected to be a reference for further research and are expected to be used as evaluation material and input material in improving hospital performance. This research is also expected to add insight and knowledge of the author regarding the application of the Balanced Scorecard.

Limitations in this study as explained in the Preliminary Chapter that this study was conducted only for a year in the 2018 period, it is expected that further research will increase the scope of the research object period so that the data obtained is more, so the research at UPTD Bali Mandara Provincial Hospital in Bali about the Balanced Scorecard is more complete.

\section{REFERENCES}

1. Anggraini, Z.T., \& Nuraina, E. (2014). Penerapan Balanced Scorecard Sebagai Alat Ukur Kinerja Pada Rumah Sakit Umum Daerah Dr. Harjono Ponorogo, E-Jurnal Akuntansi and Pendidikan, 3 (2): 75-85. E-ISSN: 2477-4995, P-ISSN: 2302-6251.

2. Hansen E. G., \& Schaltegger S. (2016). The Sustainability Balanced Scorecard: A Systematic Review of Architectures, Journal of Business Ethics, 133 (2): 193-22.

3. Koesomowidjojo S.R.M. (2017). Balance Scorecard. Model Pengukuran Kinerja Organisasi Dengan Empat Perspektif. Cetakan Pertama. Jakarta: Raih Asa Sukses.

4. Mulyadi. (2018). Sistem Terpadu Pengelolaan Kinerja Personal Berbasis Balanced Scorecard. Cetakan Keempat. Yogyakarta: UPP STIM YKPN.

5. Niemiec, A. (2016). Strategic Map for Hospital Management Perspectives and Prioritie, Journal Economic and Sociology, 9 (3): 63-75.

6. Rangkuti, F. (2018). SWOT Balance Scorecard. Teknik Menyusun Strategi Korporat Yang Efektif plus Cara Mengelola Kinerja and Risiko. Cetakan Ketigabelas: Juli 2018. Jakarta: PT. Gramedia Pustaka Utama.

7. Sudra, R.I. (2010). Statistik Rumah Sakit. Edisi Pertama. Yogyakarta: Graha IImu.

8. Sugiyono. (2016). Metode Penelitian Kuantitatif, Kualitatif, and R\&D. Cetakan Ke-23. Bandung: Alfabeta.

9. Syamsuddin, A.R., \& Damaianti, V.S. (2011). Metode Penelitian Pendidikan Bahasa. Cetakan Kedua. Bandung: PT. Remaja Rosdakaraya. 